\title{
ORTALAMA HIZ UYGULAMALARINDA YASAL KONULAR: HIZ İHLALİ ÜZERİNE BİR UYGULAMA VE ANALİZ
}

\author{
Arzu ILGAZ* , Mehmet SALTAN² \\ ${ }^{1}$ Akdeniz Üniversitesi, Yapı İșleri Daire Bașkanlığı, Antalya, Türkiye \\ 2 Süleyman Demirel Üniversitesi, Mühendislik Fakültesi, İnșaat Mühendisliği Bölümü, Isparta, Türkiye
}

\begin{tabular}{ll}
\hline Anahtar Kelimeler & Özet \\
\hline $\begin{array}{l}\text { Ortalama hız tespit sistemi, } \\
\text { Yasal düzenleme, }\end{array}$ Ortalama hız uygulaması, hız kontrolü ve trafikyaptırımı amacıyla motorlu araçların \\
Ceza, & ortalama hızlarını ölçen ve hız sınırlarını aşan araçlara ceza kesilebilmesini sağlayan \\
Hız davranışı. & bir trafik emniyeti tedbiridir. Bu sistem, dünya çapında son derece yüksek seviyede \\
& motorize olmuş ülkelerde popülerliği artan yeni ve gelişmiş bir teknolojik \\
& yaklaşımdır. Bu makalede, ortalama hız tespit sistemi kurulurken ve uygulanırken \\
& göz önüne alınması gereken çok sayıda yasal düzenlemeleri içeren konuların özeti \\
& sunulmakla beraber, bir üniversite kampüsündeki düşük hız limitli güzergâhlar \\
& üzerine kurulan ortalama hız tespit sisteminin hız ihlali yapan ve yapmayan \\
& sürücüler üzerindeki olumlu etkileri değerlendirilmiştir. Kampüs sınırları içerisinde \\
& 20, 30 ve 50 km/s olmak üzere farklı hız limitlerine sahip güzergâhlarda önce gizli \\
& (1. Evre), sonra herhangi bir cezai yaptırım olmaksızın sadece uyarı ve duyurular ile \\
& (2. Evre) mobil olarak uygulanan böylesi uygulama sistemiyle, sürücülerin hız \\
& sınırlarına uyumunda artış, hız yapma ve aşırı hız yapma davranışında da azalma \\
& olmuştur. Hız yapma sınırları belirlenirken ülkemizde uygulanan ceza oranları göz \\
& önüne alınmıştır. Araç sürücülerini hız limitlerine uyum sağlamak yolunda teşvik \\
& edebileceğini göstermesi bakımından bu çalışma önem arz etmektedir. Hız \\
& sınırlarına daha yüksek bir uyum sağlanabilmesi için ihlallerinin takibinde bir cezai \\
& yaptırım sağlanabilir.
\end{tabular}

\section{LEGAL ISSUES IN AVERAGE SPEED ENFORCEMENT: AN APPLICATION AND ANALYSIS ON SPEED VIOLATION}

\begin{tabular}{l} 
Keywords \\
\hline Average speed enforcement,, \\
Legal regulations, \\
Violation, \\
Fines,
\end{tabular}

Speeding behavior

\begin{abstract}
Average speed enforcement is a traffic safety measure that measures the average speeds of vehicles thus enabling to fine those who speed in order to enforce speed control and traffic measures. This system is a new and developed technological approach with increasing popularity in highly motorized countries all over the world. In this study, a summary of the many issues related with the legal regulations that need to be taken into consideration when setting up and applying Average Speed Enforcement System has been presented in addition to an evaluation of the positive effects of average speed enforcement set up at a university campus on low speed limit sections on drivers who violate and do not violate the speed limits. An increase in the obeying of drivers to speed limits in addition to a decrease in the speeding behavior were observed as a result of a system that was applied first as secret ( $1^{\text {st }}$ stage $)$ and next as mobile with no enforcement sanctions but only with warnings and announcements ( $2^{\text {nd }}$ Stage) within the campus borders at sections with different speed limits of 20,30 and $50 \mathrm{~km} / \mathrm{h}$. The fine levels applied in our country were taken into consideration while determining the speeding limits. This study is important for showing that it can encourage drivers to obey the speed limits. An enforcement sanction may be put into effect following the violations in order to increase the ratio of obeying speed limits.
\end{abstract}

\footnotetext{
* ilgili yazar \Corr. Author: arzuilgaz@akdeniz.edu.tr, +90-242-310-1596
} 


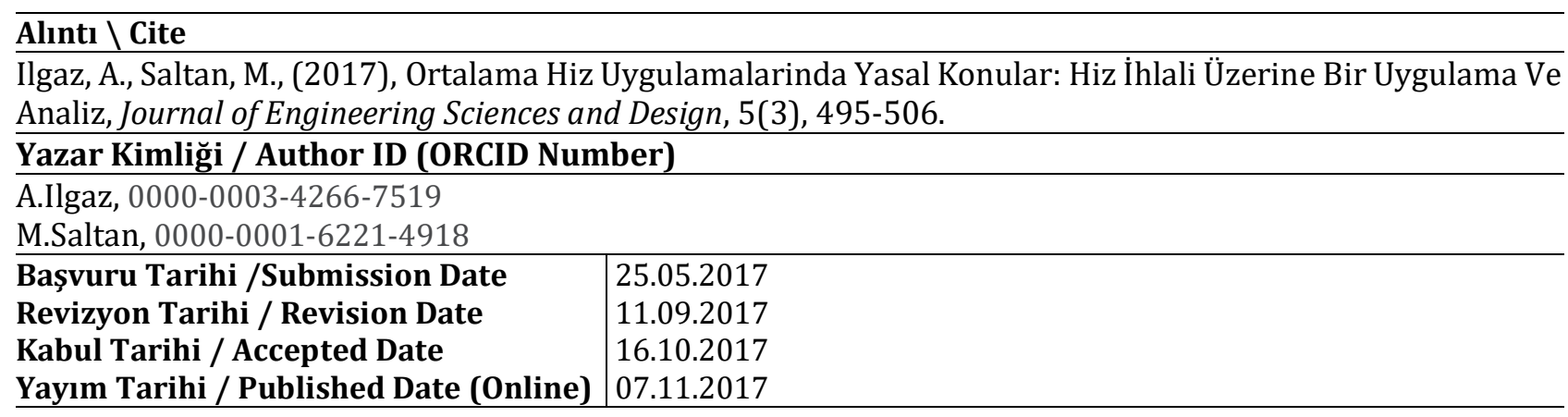

\section{Giriş}

Trafikte yüksek hız problemini çözmek için her ülkede çeşitli hız denetim sistemleri uygulanmaktadır. Bu sistemler arasında son yllarda en yaygın olanı "Ortalama Hiz Tespit Sistemi"dir (OHTS). Bu sistemin temel görevi, hız kontrolü ve trafik yaptırımı amacıyla motorlu araçların ortalama hızlarını ölçmektir. Sistemin avantajı, bir yol kesiti boyunca ortalama hızın kaydedilmesidir, bu da sürücülerin yüksek miktarda hız sınırına uymasını sağlamaktadır. Dolayısıyla bu durum araç hızı farklarında düşüş, artan bir araçlar arası mesafe, daha homojen bir trafik akışı ve artan trafik kapasitesiyle sonuçlanacaktır. Kesit kontrolü trafik akıșındaki bu uyumlulaștırmadan dolayı, mevcut altyapının daha iyi kullanılmasını, trafik emisyonları ve trafik gürültülerinin azaltılmasını da sağlamaktadır. OHTS ile mevcut araştırmalar, araç hızlarındaki düşüşle aynı doğrultuda olacak şekilde, özellikle ölümcül ve ciddi yaralanmalarla sonuçlanan kazalar olmak üzere tüm kaza tiplerinde önemli düşüşlerin gerçekleştiğini ortaya koymuştur. (Stefan, 2005; Collins, 2007; Koy ve Benz, 2009; Speed Check Services, 2009; Cascetta vd., 2011; Soole vd., 2012; De Pauw vd. 2014).

OHTS kurulurken önüne alınması gereken, teknolojik özelliklerin ötesinde, yasal düzenlemeleri de içeren bir çok konu mevcuttur. Bir OHTS'nin kurulumundan önce, sistemden sorumlu yetki merciiler bu teknolojinin tip onayın ve sertifikasını gerektirmektedir. Yasal gereklilikler, yargı yetki alanları (farklı ülkeler) arasında değişiklik göstermektedirler (Soole vd., 2012). Özellikle sistemin kurulumundan sonra, sistemin işaretlerle sürücülere duyurulmasını sağlamak, sistem uygulamasında görevli polis ve ulaşım kurumlarının yetki kapsamını belirlemek, hız ihlalleri, hız toleransları, ceza uygulamaları ve sürücü sorumluluğu konularının kapsamını belirlemek, depolanan araç verilerinin gizliliği ve güvenliğini güvenceye almak konuları önem arz etmektedir. Bu konuları güvence altına almak konusunda en şeffaf ve güvenilir yaklaşımlardan biri, bu konuda bir yasal düzenleme yapmak ve uygulama gerekliliklerini ortaya koymaktır. Dünya çapındaki yargı yetki alanları, bu konudaki yasal düzenleme zorunluluğu derecesi ile ilgili ciddi ölçüde farklılıklar göstermektedirler (Soole vd., 2012). Ayrıca ülkemizde son yıllarda uygulanmakta olan OHTS yaklaşımı hakkındaki yasal konuları değerlendiren araştırmalarda da bir yetersizlik söz konusudur ve dolayısıyla, akademik anlamda bir girișimin yapılması gereklidir.

Bu makalede, OHTS'de yasal konular ve uygulamalar kapsamında uluslararası literatür taranmış ve değerlendirilmiştir. Ayrıca OHTS sistemi yüksek hız problemi olan bir üniversite kampüsüne mobil araçlar ile, gerekli bütün altyapı ve yazılımı ile kurulmuş, 1 . ve 2. Evre (önce/sonra) hız etütleri ile aynı sürücülerin 1.'si gizli 2.'si ise ilan edilmiş iki evredeki ortalama hız değerleri 11 farklı güzergahta $(20,30$ ve $50 \mathrm{~km} / \mathrm{s} \mathrm{hız}$ limitli) ölçülmüștür. Uygulamanın sonunda sistemin "(1) hız toleransları dâhilinde hız ihlali yapmayan, (2) aşırı olmayan hız davranışında bulunarak hız ihlali yapan ve (3) aşırı hız davranışında bulunarak hız ihlali yapan sürücüler" üzerinde ne denli etkili olduğu tespit edilmiş ve istatistiksel analizler ile değerlendirilmiştir. Bu çalışmanın, ülkemizde ve diğer ülkelerde yapılan uygulamalardan farkı; plaka okuyan kameraların montajının sabit bir yapı üzerine değil de gezici (mobil) araçlar üzerine yapılmış olmasından dolayı, plaka okumalarının istenilen zaman ve istenilen her noktada yapılabilme olanağının olmasıdır. Ayrıca bu tür uygulamalar geçmişte otoyol koşullarıyla sınırlandırılmıştır, ancak bir dizi ülke bu sistemi kentsel anayollarda da kurmaya başlamıștır (örneğin, İngiltere, Avustralya). Bu çalışmada ilk defa bir üniversite kampüs alanı içindeki güzergâhlar kullanılmıştır.

\section{Bilimsel Yazın Taraması}

Ortalama hız uygulaması, bir yol ağı kesiti boyunca çok sayıda konuma iki veya daha çok kameranın yerleştirilmesini içerir. Ortalama hiz kamera sistemleri için birincil işleme gerekliliği Otomatik Plaka Tanıma (ANPR) ve Optik Karakter Tanıma (OCR) yazılımları olarak belirtilmiştir. Bahsedilen "birincil işleme gerekliliği", araç plakalarını ve diğer ilgili verileri yakalama ve tanıma işlemlerini sağlamaktadır (Soole vd., 2012). ANPR, sistem kameralarından geçen araçların ruhsat/plakalarını otomatik olarak algılayan ve okuyan AVI (otomatik araç tanımlama) sistemlerinin bir çeşididir (Young ve Regan, 2007; 
ANPR Systems, 2014). OHTS tipik olarak şu șekilde çalışır: Giriş ve çıkış kameraları araçların görüntüsünü yakalar ve ANPR/OCR yazılımı tarafından işlenmesi için spesifik bir dosya formatına dönüştürür (örn.; JPEG, TIFF, bitmap). Görüntünün yakalanması sırasında, ihlalin tarihi, saati ve konumunun yanı sıra sistem parametreleriyle de ilgili bilgiler toplanır. Genel olarak 'parmak izi' (fingerprint files) olarak anılan bu veriler her bir kamera sahasında toplanır. Bir iletișim bağlantısı parmak izlerini (her biri $1 \mathrm{kB}$ ) merkezi bir ofise gönderir ve her çıkış parmak izi, giriş parmak izlerinden oluşan alt setle karşılaştırılır. Eşleșen parmak izleri, hız ihlali yapanları tanımlar ve hesaplanan hız, sisteme tanımlanmış ihlal eşiğinin üzerindeyse kaydedilir. Tüm diğer görüntüler ve parmak izleri, herhangi bir hız ihlali tespit edilmediği takdirde yazılım tarafından reddedilir. Hız ihlalinde bulunanların geriye kalan görüntüleri daha ileri aşamada işleme ve otomatik plaka tanıma için polisin işleme sistemine aktarılır (Şekil 1.) (Gil ve Malenstein, 2007; Orozova-Bekkevold, vd., 2007; Grunnan vd., 2008).

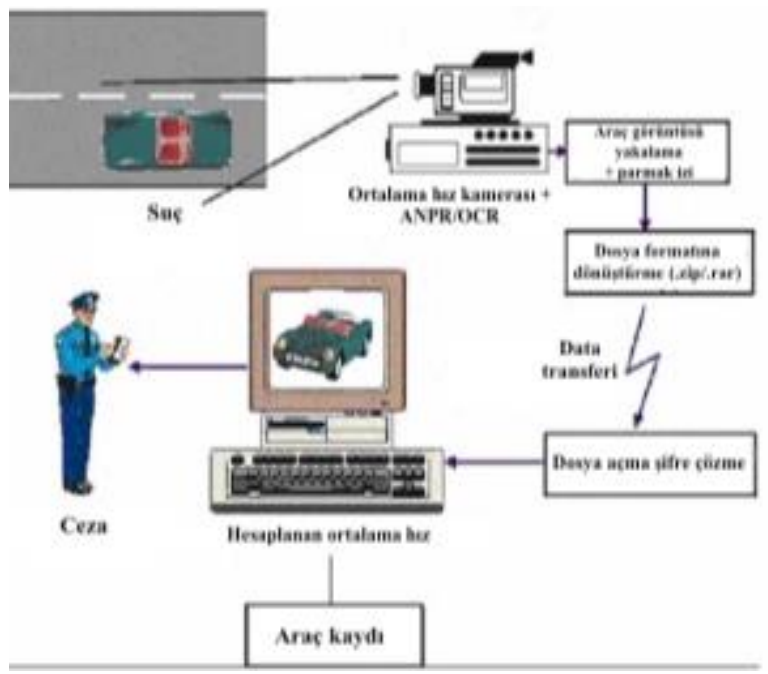

Şekil 1. OHTS yapısı (Organisation for Economic CoOperation and Development, 2006)

\subsection{Hız ihlali yapan araçların oranı, aşırı ve düşük seviyede hız yapma}

Çok sayıda çalışma, OHTS uygulamasının sürücülerin hız sınırlarına uyması konusunda yüksek oranlar sağladığını göstermektedir. Günlük trafik hacimleri yüksek olduğunda bile ihlal oranları genellikle $\% 1$ 'den düşük olarak bildirilmiştir. Çalışmalar, "hız sınırını aşan araç oranlarında" \%90'a varan düşüşler bildirmiştir ve bu uygulamanın özellikle de "aşırı hız yapma" davranışını azaltma konusunda oldukça etkili olduğunu göstermektedir (Gains vd., 2005; Schwab, 2006; Soole vd., 2012; Fleiter vd., 2013). Avustralya'nın Victoria Eyaleti'ndeki Hume otoyolu üzerinde kullanılan bir OHTS uygulamasının sağladığı uyum oranlarını değerlendirirken, günlük olarak hız ihlalleri için yaklaşık 1000 aracın işlem gördüğünü
(100.000 araca kadar çıkabilen yaklaşık bir günlük trafik hacmi içinde), bunun da yaklaşık \%1-2'lik bir ihlal oranı oluşturduğu ifade edilmiștir (Cameron, 2008; Soole vd., 2012).

"Düşük seviyede hız yapma" davranışıyla ilgili olarak bunun hız yapma davranışı için bir gerekçelendirme olduğu ve küçük hız ihlallerinde yaptırım uygulamak için az da olsa bir gereğin olduğu gerçeği tartışılmıștır. Ancak, sürücülerin hız sınırını küçük miktarlarda da olsa aşmasının, kaza tehlikesi ve ağır yaralanma olasılığında önemli artışlara sebep olduğu ve araç hızlarında küçük azaltışlarının bile kaza sonuçlarında önemli düşüşler sağlayabileceği gözlenmiștir (Kloeden vd., 2002; Nilsson, 2004; Soole vd., 2012). Bu nedenle, sürücülerin düşük seviyede hız yapma davranışını azaltmak önemli bir yol emniyeti hedefidir. Bu kapsamda hız denetim sistemlerine karşı şüpheci yaklaşan bir kamuya ve medyaya "hız uygulama girişimlerinin, minör ve önemsiz trafik ihlallerinden gelir toplamaktan ziyade, iyileștirilmiş yol emniyeti sağlamanın amaçladığının" anlatılması hayati bir önem taşımaktadır. $\mathrm{Bu}$ sorun, Avustralya'nın yakın zamanda yayınlanan Ulusal Yol Emniyeti Stratejisi 2011-2020 içinde önemli bir zorluk olarak vurgulanmıştır (Australian Transport Council, 2011).

İtalya'daki A56 kent otoyolu üzerinde etkinleştirilen OHTS'nin sürücü hız ve emniyeti üzerindeki etkileri değerlendirilmiştir. Sistemin aşırı hız yapma davranışını azaltmak konusunda daha fazla etkili olduğu gözlemlenmiștir. Gerçekten de, hız sınırını 10 $\mathrm{km} / \mathrm{s}^{\prime}$ ten fazla aşan hafif araçlarda \%31'den \%9'a (\%72'lik bir azalma) ve hız sinırını $20 \mathrm{~km} / \mathrm{s}^{\prime}$ ten fazla aşan hafif araçlarda \%14'ten \%4'e (\%84'lük bir azalma) düşüş görüldüğü belirtilmiştir (Montella vd., 2014).

\subsection{Ortalama Hiz Uygulamalarında Yasal Düzenlemeler}

OHT sistemi dünyada ilk olarak 2010 yılında Avustralya'nın Victoria Eyaletinde "Yol Emniyeti Kanunu (1986) ve Yol Emniyeti (Genel) Düzenlemeleri (1999)" adı altında yasalaștırılmıştır. Victoria, teknolojiyi uygulamaya koyan ilk Avustralya yargı yetki alanı olmuş, onu daha yakın zamanda ya tam işletim ya da deneme şeklindeki uygulamalarıyla New South Wales, Queensland ve Güney Avustralya bölgeleri takip etmiştir (Soole vd., 2012). Ülkemizde ise OHTS uygulamaları, TEDES (trafik elektronik denetleme sistemi) çalışmaları kapsamında Karayolları Trafik Kanunu'nun (2918 Sayılı Kanun) Ek 16'ncl maddesine dayanarak yürütülmektedir. Sistem; karayollarında can ve mal güvenliğini sağlamak, düzenli ve güvenli trafik akışını sağlamak, trafik kural ihlallerini izlemek, görüntülemek, tespit etmek ve idari para cezası uygulamak üzere kurulan ana izleme ve görüntüleme sistemidir (KTK, 2013) . 


\section{Yol İşaretleri}

Dünya çapında OHTS'erin çoğunluğu, sürücüleri bir uygulama koridoruna girdikleri konusunda uyaran işaret tabelaları kullanılmak suretiyle "sürücülere duyurulmuş biçimde" işletilmektedir. Ancak, işaretlerin derecesi ve spesifikliği yargı yetki alanları arasında farklılık göstermektedir. Spesifik olarak, işaret yerleşimi, uygulama koridorundan önce konumlanan tek bir tabeladan, uygulama kesitinden önce ve bu kesit içinde kullanılan çok sayıda işaret tabelasına kadar değișebilmektedir. Ayrıca, işaret tabelaları üzerinde bulunan bilgilerin spesifikliği de belirli biçimde ortalama hız kontrolüne atıfta bulunan tabelalardan, hız kameralarının varlı̆̆ konusunda daha genel uyarılara kadar farkllık gösterir. Kameraların anlık hızları yakalama yeteneğinin yanı sıra ortalama hızı hesaplama yeteneğine de sahip oldukları bu sistemler için uygulama kesitinden önce ve bu kesit içinde bir işaret yaklaşımı daha uygun olabilmektedir. OHTS için işaret gerekliliklerinin yasal düzenlemeye dahil olması veya basit biçimde önerilerden ibaret olması derecesi de yargı yetki alanları arasında farklılık gösterir (Soole vd., 2012).

\section{Polis ve ulașım ajanslarının yetkileri}

Avustralya'nın Victoria Eyaleti'nde OHTS'nin işlemci sisteminin bakım sorumluluğunu Trafik Kamera Hizmetleri Tedarikçisi yürütmektedir ve dolayısıyla yol emniyet kamera ağı tarafından yakalanan tüm vakaları onlar doğrulamaktadır. Victoria Polisi, OHTS ile ilgili bakım ve yönetim işlemlerinin dışında tutulmuş olsa da, tüm ihlaller konusundaki yetkili merci olarak önemli bir göreve sahip olmayı sürdürmektedir (Soole vd., 2012).

Birleşik Krallık çapındaki emniyet kamerası programları ise ilgili uygulamacılar tarafından oluşturulan spesifik emniyet kamerası ortaklıklarıyla işletilmektedir. Yani sistemi uygulayan tek bir kuruluş yoktur. $\mathrm{Bu}$ ortaklıklar ülke seviyesindedir ve birbirlerinden büyük ölçüde ayrılmıştır. Genel olarak, yerel yönetimler otoban ağını yönetir ve kalıcı uygulama sistemlerinin kurulumu ve bakımından bunlar sorumludurlar. Diğer yandan polis, ihlal bildirimlerinin yaptırım ve yönetiminden, Galler Mahkeme Hizmetleri ise para cezalarının ödemelerinin alınmasından sorumludur. İhlal bildirimlerinin idaresinden ise polis kuvvetleri sorumludur. Yol çalışması müteahhitlerinin görevi ise yol işaret tabelalarının denetimlerini günlük olarak sağlamaktır (Soole vd., 2012). Türkiye'de ihlaller konusunda yetkili merci Emniyet Genel ve Bölge Müdürlüklerine bağlı Trafik Denetleme Müdürlükleri'dir (Tedesceza, 2016).

\section{Hiz ihlallerine ceza uygulamaları}

OHTS, dünyada hız yaptırım uygulama yöntemlerinden biridir ve araçlar için tespit edilme olasılığı neredeyse \%100'e yakındır (Malenstein, 1997; Korthof, 2014). "Şekil 2.", Hollanda'da bulunan OHTS'lerdeki hız ihlallerinin yıllık ceza sayısı olarak ifade edilişini göstermektedir. Diyagramda da görülebileceği gibi, 2007'de ihlallerde bir zirve gerçekleşmektedir. Bunun sebebi; sürücülerin bu yeni tip yaptırım uygulamasına alışmakta zorlanması olabilir veyahut OHTS'den geçen araç sayısında artış olması da olabilir; çünkü Hollanda'da verilen cezaların toplam sayısı da bu yıl içinde küçük bir artış göstermektedir (Korthof, 2014).

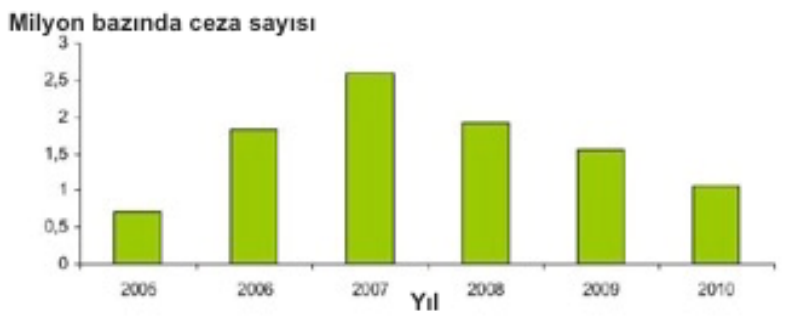

Şekil 2. Kesit kontrolü cezalarının sayısı (Korthof, 2014)

OHTS uygulamalarında ceza uygulama eşiği ülkeler arasında farklılık gösterebilmektedir. Flaman (Belçika) otobanlarında cezalar; $10 \mathrm{~km} / \mathrm{s}^{\prime}$ lik bir hız ihlali yapma seviyesine kadar 50 Euro'dur ve ilk 10 $\mathrm{km} / \mathrm{s}$ 'ten sonraki her bir $\mathrm{km} / \mathrm{s}$ aşımı için para cezası tutarına 5'er Euro daha eklenir. $40 \mathrm{~km} / \mathrm{s}$ veya daha fazla hız ihlali olması durumunda ise sürücüler mahkemeye çkarılır ve 55 Euro ile 2750 Euro arasında değişen bir para cezasıyla, 8 günden 5 yıla kadar değişen araç kullanma yasağı alırlar (De Pauw vd., 2014). İtalya'da $10 \mathrm{~km} / \mathrm{s}$ 'e (artl $5 \mathrm{~km} / \mathrm{s}^{\prime}$ lik bir uygulama toleransına sahip) kadar yapılan hız ihlallerinde, ihlali gerçekleştiren sürücüler 41 ila 168 Euro arasında bir ceza öderler. 10 ile $40 \mathrm{~km} / \mathrm{s}$ arasında bir hız ihlali seviyesinde ise ceza 168 ile 674 Euro arasındadır ve ihlali gerçekleștirenlerin sürücü ehliyetlerine de 3 ceza puanı yazılır. 40 ile $60 \mathrm{~km} / \mathrm{s}$ arasındaki bir hız ihlali seviyesinde, ihlali gerçekleştiren sürücüler 1 ila 3 ay arasında bir sürüş yasağı ve 527 ila 2108 Euro arasında bir para cezası alırlar. $60 \mathrm{~km} / \mathrm{s}$ üstündeki bir hız ihlali seviyesinde ise, ihlali gerçekleştiren sürücüler 6 ila 12 ay arasında bir sürüş yasağı ve 821 ila 3287 Euro arasında bir para cezası alırlar (Montella vd., 2014; 2015).

Türkiye'de ise hız ihlali yaptığı tespit edilen araçlara, Emniyet Müdürlüğünce cezai müeyyide uygulanmaktadır. TEDES tarafından tespit edilen kural ihlali, görevliler tarafından ihlalin gösterildiği resimli "Trafik Kuralı İhlal Tespit Formu ve Trafik İdari Para Cezası Karar Tutanağı'na” dönüştürülerek postaya verilir. Postaya verilen ceza tutanağı araç ruhsat bilgilerinde kayıtlı olan sürücü adresine 5-15 iş günü içerisinde ulaştırılmaktadır (Ornek vd., 2013). Belirtilen hız limitlerini ne kadar geçerse sürücünün 
cezası o oranda artmakta; KTK madde 52/2-a'ya göre hız sınırını \%30'a kadar aşan sürücülere 199,55TL, KTK madde 52/2- b’ye göre hız sinırını \%30'dan fazla așan sürücüșere 412,82TL ceza kesilmektedir. Örneğin İstanbul'da uygulanan sistemde hız ihlali yaptığı tespit edilen araçlara, İstanbul Emniyet Müdürlüğü'nce cezai müeyyide uygulanmaktadır. Sistem, maksimum hız limiti $70 \mathrm{~km}$ olacak şekilde değișik hızlarda kontrol sağlamaktadır. Belirtilen hız limitlerini ne kadar geçerse sürücünün cezası o oranda artmakta; hız limiti $50 \mathrm{~km}$ verildiğinde; $55-65 \mathrm{~km} / \mathrm{s}$ arası (\%10-30 arası) 154 TL, 65 km/s'yi (\%30'dan fazla) geçerse $319 \mathrm{TL}$, hız limiti $70 \mathrm{~km} / \mathrm{s}$ olarak belirtildiğinde ise 78-91 km/s arası 154 TL, 91 km/s'yi geçerse 319 TL ceza kesilmektedir (Tedesceza, 2016).

\section{Hız sınırı ceza uygulamalarında hız toleransları}

Hız toleransı, araçların bir ceza almadan seyahat edebileceği hızdır. OHTS ile ilgili uygulama yaptırımı toleranslarında yargı yetki alanları arasında önemli ölçüde bir heterojenlik söz konusudur. Belirli bir yargı yetki alanındaki çeşitli sosyo-politik faktörlerin uygulama yaptırım eşiğini etkileme olasılığı yüksektir ve bir yargı yetki alanı içinde farklı tipteki hız tespit cihazları için farklı tolerans seviyelerinin kullanılması mümkündür (Soole vd., 2012). OHTS ile tespit edilen ve hız yapma davranışının bir yol ağı boyunca ölçüm yapılabildiği göz önüne alındığında, OHTS uygulamasında anlık hız kontrollerine göre daha düşük bir uygulama yaptırım eşiğinin kullanılabileceği öne sürülmüștür (Cameron, 2008; Lynch, 2010).Hız limitleri dahilinde verilen hızın, aktüel (gerçek) hızın yüzde kaçı dahilinde yasal uygulama toleransı olması şartı ve uygulaması ülkeden ülkeye farklılık gösterebilmektedir (Cameron vd., 2003). İsviçre'de $100 \mathrm{~km} / \mathrm{s}^{\prime}$ e kadar hız sınırına sahip yollarda $5 \mathrm{~km} / \mathrm{s}$ ve daha yüksek hız sınırlarına sahip yollarda 6-7 km/s'lik yasal bir uygulama toleransı mevcuttur. Araştırmacılar sistemin hassasiyetini vurgulamışlar; ancak teknik bir bakış açısıyla $1 \mathrm{~km} / \mathrm{s}^{\prime} \mathrm{lik}$ bir toleransın da yeterli olacağını belirtmişlerdir. Birleşik Krallık'ta Emniyet Amirleri Birliği, uygulama yaptırımının, hız sınırının \%10'u + 2 mil/s'e denk gelen bir eşikle uygulanmasını önermektedir (örn.; 50 mil/s'lik bir bölgede $57 \mathrm{mil} / \mathrm{s}$ bir eşik). \%10'luk payın bir yasal gereklilik olduğu; ancak, ilave $2 \mathrm{mil} / \mathrm{s}$ 'in bir Emniyet Amirleri Birliği politikası gerekliliği olduğu bildirilmiştir. İskoçya'da A77 sistemi, İskoçya'daki diğer emniyet kameralarıyla bağlantılı olarak benzer minör bir uygulama toleransina izin vermektedir, böylece ihlaller hız sınırının az miktarda üzerinde bulunan bir eşikte kaydedilir. Hollanda'da ise sürücülere \%3'lük bir uygulama yaptırımı toleransı sağlanmıștır ve bu tolerans tüm hız uygulaması yaklaşımlarında ortaktır (Soole vd., 2012). Ülkemizde OHTS uygulama yaptırımı hız sınırının \%10'una kadar bir eşikle uygulanmaktadır (Tedesceza, 2016).

\section{konusu}

Yargı yetki alanlarında genel olarak ihlal sorumluluğu yükünün sürücüde veya araç sahibinde olmasıyla ilgili yasal düzenlemelerin hesaba katılması gerekebilir. Çoğu uluslararası yargı yetki alanında bu konu, OHTS'nin uygulanmasını engelleyen temel faktörlerden biriyken, Avustralya'da bu çok daha az geçerlidir. Tüm Avustralya eyaletlerinde kamera tarafından tespit edilen ihlallerin sorumluluk külfeti araç sahibine aittir. Araç sahibi sorumluluğu konusunda, bireylerin uygulama koridorundan geçerken sürücü değiştirmiş olduklarını iddia edebilecekleri gibi potansiyel sorunlar vurgulanmıștır (Cameron, 2008; Soole vd., 2012).

Çoğu Avrupa ülkesinde ise, sürücünün fotoğrafla tanımlanması gerekliliği mevcuttur ki, bu da yolcuların tanımlanabilir fotoğraflarının depolanması konusundaki kısıtlamalar sebebiyle işleri karmaşıklaştırmaktadır (Gil ve Malenstein, 2007; Kallberg vd., 2008, Soole vd., 2012). Sürücü tanımlanamazsa ve suçlu aracın sahibi bir sürücü adı veremezse, suçlamalar düşmekte ve bu da sıklıkla polis ve ulaşım yetkililerinin zararına olmaktadır (Organisation for Economic Co-Operation and Development, 2006; Soole vd., 2012). Birleşik Krallık'ta, ihlal sırasında sürücünün bilgilerini sağlamak konusundaki sorumluluk külfeti araç sahibindedir. Dahası, bu bilgileri 28 gün içinde paylaşmamak bir suç sayılır ve 2.500 Pound'luk bir para cezası ve altı trafik ceza puanıyla sonuçlanır. Kendi filoları içindeki sürücülerin bilgilerini paylaşmayan şirketler için daha yüksek cezalar mevcuttur (Soole vd., 2012).

Avusturya'da ortalama hız uygulamasının ilk yıllarında, yabancı sürücüler için mevcut olan yasal boşluklardan dolayı OHTS tarafindan tespit edilen bazı ihlallerin takibi konusunda zorluklar yaşanmıştır. Bazı yabancı ülkelerden gelen sürücülerin yasal takibi ancak fotoğraflar sürücüyü tanımlayabiliyorsa mümkün olmaktaydı (kendi ilgili ülkelerindeki yasalardan dolayı). Avusturya'da hız ihlali yapanların tümünün \%60'a varan bir oranda yabancı sürücüler olduğu tahmini göz önüne alındığında, bu durum yasal olarak bir sorun teşkil etmekteydi (Townsend, 2006; Soole vd., 2012). Para cezalarının karşılıklı tanınması konusunda anlaşma yalnızca Almanya ve İsviçre arasında mevcut olduğundan, yabancı hız ihlalcilerinin çoğu cezaya çarptırılamamaktaydı (Grunnan vd., 2008) Bunun sonucunda, Avrupa Birliği Konseyi , tam olarak yürürlüğe 2007 yılında giren ve sınırlar arasında para cezalarının karşılıklı olarak tanınmasını sağlayan bir yasal düzenleme yapmıştır. Dolayısıyla, sürücünün tanımlanması Avusturya'da bir gereklilik olmaktan çıkmıştır (Townsend, 2006; Soole vd., 2012).

\section{Çoklu ihlal politikaları}


"Bitişik uygulama koridorları içeren ortalama hız kameralarından oluşan sistemler" veya "aynı zamanda hem ortalama hız hem de anlık hız kameraları olarak da çalışmak üzere yapılandırılan sistemler" veya "ortalama hız kameralarının arasındaki orta blokta bir sabit hız kamerası mevcut olan sistemler" ile ilgili özel bir konu vardır. Böyle sistemler genellikle sürücüleri aynı ihlal için çok sayıda ihlal cezası almaya karşı korumak amacıyla bir "çoklu ihlal politikası" gerektirir. $\mathrm{Bu}$ politikanın özellikleri yargı yetki alanları arasında farklılık gösterse de, tipik olarak hız sınırının çok üzerinde yapılan hız ihlallerine ağırlık vermektedir (Lynch, 2010; Soole vd., 2012). Yapılan incelemeler sonucunda, çoğu yargı yetki alanının yalnızca geçerli en yüksek cezaya sahip en ciddi ihlali kovuşturduğu bulunmuştur. Yani yukarıda bahsedilen uygulamaların herhangi birinde, belirli bir araç tarafından işlenen tüm ihlallerin gözden geçirilmesini gerektirecek ve günün aynı saatinde, aynı sahada, bir aracın anlık ve ortalama hız ihlalleri bulunursa, bu durumda en yüksek cezaya sahip ihlal seçilecek ve diğerlerine ihlal bildirimi ve ihlal cezası uygulanmayacaktır. Bu yasal düzenleme, ortalama hız ihlalinin varlığının, aynı konumda bir anlık hız ihlaline karşı bir savunma oluşturmadığını da açıkça belirtir (Lynch, 2010).

Hollanda'da sürücüleri, tek bir uygulama koridoru boyunca birçok kez ceza almaktan korumak için bir çoklu ihlal politikası yürütülmektedir (Soole vd., 2012). Hollanda'daki bazı OHTS'ler çok sayıda yol kesitinden oluşmaktadır. Bir araç, bitişik kamera çiftlerinden oluşan kesit kontrolüne girdiğinde, tüm kesitlerden geçen araç her kamera çiftleri tarafından izlenir, ancak yalnızca bu araç için ölçülen en yüksek ortalama hızın gerçekleştiği kesit için bir ceza uygulanır. Sonuçta tüm kesitlerde hız sınırını ihlal eden araçlar yalnızca bir ceza alacaktır (Korthof, 2014).

Avustralya'da sistemin bitişik kamera sahaları içerdiği kesitlerde çoklu bir ihlal politikası mevcuttur. $\mathrm{Bu}$ politika, ortalama hız ağının uzunluğu boyunca verilmiş hız sınırını $10 \mathrm{~km} / \mathrm{s}$ ve üzeri aşmayan ihlallerde geçerlidir, yani bir sürücünün tek bir seyahatte bu ă̆ içinde çok sayıda ihlal işlediği belirlenirse, tüm kesit için yalnızca bir ihlal bildirimi çıkarılır. Yapılan ihlaller hız sınırını 10 km/s aşıyorsa, ihlalde bulunan sürücüye çok sayıda ihlal bildirimi gönderilir (Soole vd., 2012). İtalya'da aynı yol kesiti içinde çok sayıda ihlal için ceza yazmak kanun tarafından yasaklanmıştır. Bu sebeple, otoyolun tek bir uygulama kesitinde bulunan birbiri ardına gelen kısımlarında çok sayıda ihlalin tespit edilmesi durumunda yalnızca bir ihlal kayda geçer (Soole vd., 2012; Montella vd., 2014; 2015). Birleşik Krallık'ta çok noktalı sistemler için bir çoklu ihlal politikası bulunmakta ve buna göre, uygulama kesitinden geçerek yapilan tek bir seyahat boyunca bir sürücü tarafindan yapılan ihlallerin yalnızca en "ciddi" olanı takibe alınmaktadır (Soole vd., 2012). Ülkemizde bitişik uygulama koridorları içeren güzergâhlar için çoklu ihlal politikası ile ilgili çalışma ve araştırmalar devam etmektedir.

\section{Gizlilik konusu}

OHTS tarafindan depolanan verilerin gizliliği ve güvenliğiyle ilgili endişeler de uygulamacı ve kullanıcılar tarafından düzenli olarak ifade edilmektedir $\mathrm{Bu}$ endișeler, özellikle depolanan verilerin güvenliğini sağlamayı içermektedir. Dahası, sürücülerin tanımlanması ve plaka bilgilerinin başka veri tabanlarıyla potansiyel olarak eşleştirilmesiyle bağlantılı gizlilik sorunlarına da çözüm bulunmalıdır. Ayrıca veri tabanları yönetimi ve ihlal bildirimlerinin dağıtımının devlet tarafından mı, yoksa özel bir kurum tarafından dış kaynaklı olarak mı yapıldığına bağlı olarak da veri gizliliği ve güvenliği endișeleri ortaya konulabilmektedir (Gil ve Malenstein, 2007; OrozovaBekkevold vd., 2007; Parliamentary Travelsafe Committee, 2008; Soole vd., 2012).

OHTS uygulamasını dünya çapında ilk deneyen ve uygulayan Hollanda, gizlilik konusuna da ilk olarak değinmiş ülkedir. Deneme uygulamasında bazı gizlilik düzenlemelerine uyulması gerekmiștir. Bunlar, "Kişilerin Kaydı Kanunu ve Polis Kayıtları Kanunudur". Bu kanunlar sisteme şu gibi şartları koşmaktadır: "Sistemin erişilebilirliği, yazılımın sistem güvenliği, verilerin gönderimi, depolanması ve doğruluğu". Durum bir polis operasyonuyla ilgili kişilerin kayıtlarını ilgilendirdiği takdirde Polis Kayıtları Kanunu geçerlidir. Araç ve plaka bilgilerinin geçici ve kalıcı veri tabanlarında depolanması durumundan dolayı idari olarak addedilen ihlaller Kişi Kayıtları Kanunu rejimi altında, tüm diğer ihlaller Polis Kayıtları Kanunu rejimi altında değerlendirilir (Malenstein, 1997).

Hollanda'da kurulan OHTS'lerde, verilerin bulunduğu yol kenarındaki kabinler yetkisiz girişe karşı korunmaktadır, böylece kabinleri açmak için yapılan yetkisiz girişler, sistemin anında kapatılmasıyla ve sabit diskin anında silinmesiyle sonuçlanmaktadır. Vandalizm ile ilgili herhangi bir sorunun veya sistemlerin veri bağlantısı ağı bileşenlerini hacklemekle (sistemin gizli, ulaşılamayan bilgilerini ele geçirmek) ilgili herhangi bir girişimin varlığını bildirmemiştir (Gil ve Malenstein, 2007; Grunnan vd., 2008; Soole vd., 2012). İtalya'da çalışmakta olan OHTS'lerde ülkedeki gizlilik kanunlarından dolayı yalnızca arkaya bakan kameralar kullanılmıştır; çünkü sürücü kişisel bilgilerinin korunması için yüz karartma tekniği yeterli görülmemektedir. Ayrıca, yalnızca ihlalde bulunan araçların verileri geri ofise gönderilirken, ihlalde bulunmayan araçların tüm verileri derhal silinmektedir (Soole vd., 2012; Montella vd., 2015). 


\section{Materyal ve Yöntem}

\subsection{Mobil OHTS'nin kurulduğu güzergâhlar}

Makale için belirlenen pilot bölge, Akdeniz Üniversitesi kampüsüdür. Kampüste "20, 30 ve 50 km/s" hız sınırlarını gösteren trafik işaret levhaları olmasına rağmen hız limitlerinden daha yüksek hızlarda araç kullanımı dikkat çekmektedir. Rektörlük arşiv kayıtlarından yılda 10 civarında tespit edilen kazaların sebepleri de aşırı hızlı araç kullanımından kaynaklanmaktadır. Bu güzergâhlardaki yüksek hız ve kaza problemine OHTS ile çözüm aranmaktadır.

Bu makalede kullanılan "ortalama hız" teriminin tanımı şu şekilde tarif edilebilir: "Yol kenarına yerleştirilmiş, aralarındaki uzaklık bilinen iki adet plaka okuyucu kamera, yoldan geçen araçların geçiş zamanlarını kaydeder (Şekil 3.). Bu geçiş zamanı içinde "hesaplanan ortalama $h \mathrm{iz}=\mathrm{d} /\left(\mathrm{t}_{2}-\mathrm{t}_{1}\right)$ " olup, $\mathrm{d}$ mesafesi $(300 \mathrm{~m}$ 'den başlayıp onlarca kilometreye kadar çıkabilir), sabit iki plaka okuyucu kamera noktası arasındaki mesafedir ve ortalama hız, aracın son kaydedilen geçiş zamanından $\left(t_{2}\right)$ ilk kaydedilen geçiş zamanının $\left(\mathrm{t}_{1}\right)$ çıkarılıp, bu mesafeye (d) bölünmesiyle elde edilir".

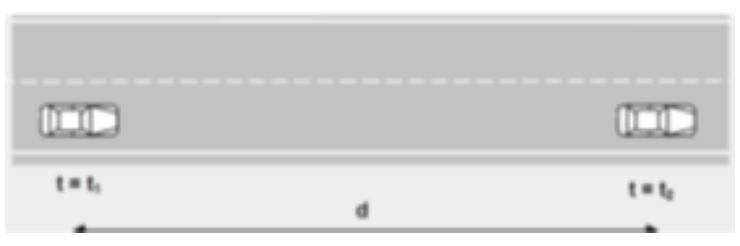

Şekil 3. Ortalama hız kavramı

Ortalama hız kameraları 2 adet ölçüm (mobil) aracı üzerine monte edilmiş olan 'ses sistemi bagajı' içinde kamufle edilerek kurulmuştur (Şekil 4.) Ölçümler için tüm aracın yanı sıra şerit konumunu da kapsayan, daha geniş bir açı görüntüsü yakalayan 2 şeritli plaka tanıma kameraları seçilmiştir.

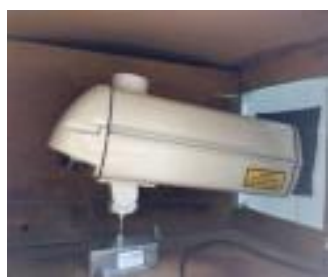

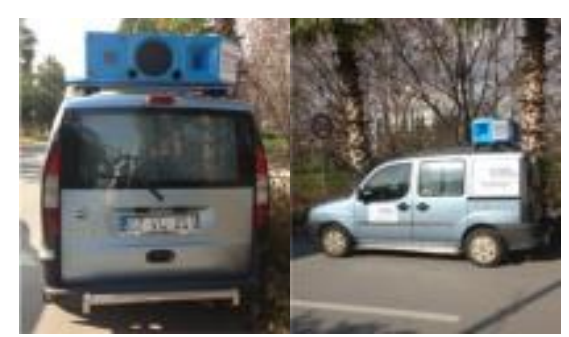

Şekil 4. Araç üzerine montajlanan ortalama hız kameraları

Mobil ortalama hız sisteminin uygulandığı farklı uzunluklardaki 11 adet güzergâh Şekil 5.'te görülmekle beraber, güzergâhların özellikleri Tablo 1.'de görülmektedir.

Tablo 1. OHTS güzergâhların özellikleri

\begin{tabular}{|c|c|c|c|c|c|c|}
\hline \multirow{3}{*}{$\begin{array}{c}\text { Nokta } \\
\text { çifti } \\
\\
\text { A } \\
\end{array}$} & \multirow{3}{*}{$\begin{array}{c}\begin{array}{c}\text { Uzunluk } \\
\text { (m) }\end{array} \\
908\end{array}$} & \multirow{3}{*}{$\begin{array}{c}\begin{array}{c}\text { Hiz } \\
\text { limiti } \\
(\mathbf{k m} / \mathbf{s})\end{array} \\
30 \\
\end{array}$} & \multicolumn{2}{|c|}{ Şerit sayısı } & \multicolumn{2}{|c|}{ Şerit genişliği(m) } \\
\hline & & & \multicolumn{2}{|c|}{ 1. nokta 2. nokta } & 1. nokt & 2. nokta \\
\hline & & & 2 & 1 & 3.50 & 3.50 \\
\hline $\mathrm{B}$ & 717 & 30 & 2 & 2 & 3.50 & 3.50 \\
\hline $\mathrm{C}$ & 890 & 50 & 2 & 2 & 3.50 & 3.50 \\
\hline D & 890 & 50 & 2 & 2 & 3.50 & 3.50 \\
\hline $\mathrm{E}$ & 425 & 30 & 2 & 2 & 3.50 & 3.50 \\
\hline$F$ & 600 & 20 & 2 & 2 & 3.00 & 3.00 \\
\hline$G$ & 600 & 20 & 2 & 2 & 3.00 & 3.00 \\
\hline $\mathrm{H}$ & 615 & 30 & 1 & 2 & 3.50 & 3.50 \\
\hline I & 594 & 30 & 2 & 1 & 3.50 & 3.50 \\
\hline $\mathrm{J}$ & 695 & 30 & 2 & 1 & 3.50 & 3.50 \\
\hline $\mathrm{K}$ & 695 & 30 & 1 & 2 & 3.50 & 3.50 \\
\hline
\end{tabular}

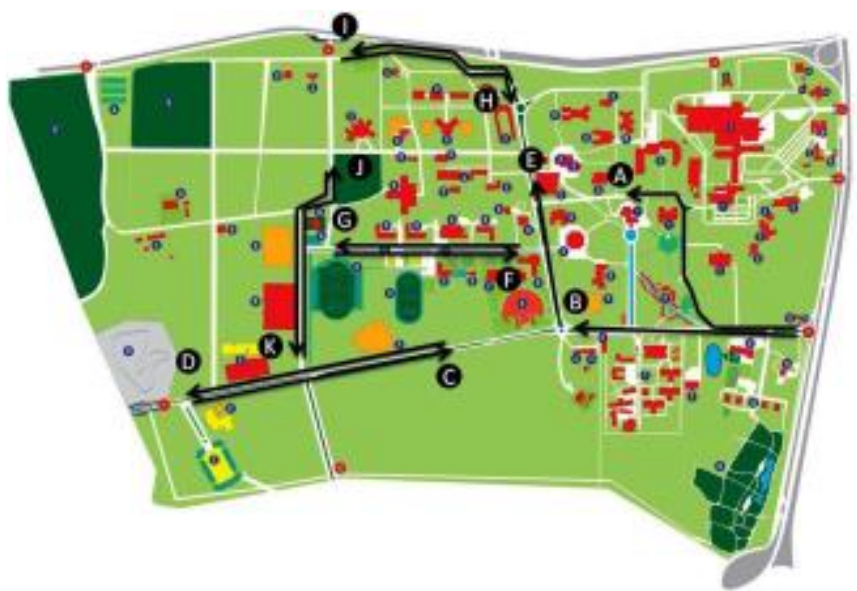

Şekil 5. Mobil OHTS'nin uygulandığı 11 adet güzergâh

\subsection{Mobil OHTS ile veri toplama}

OHTS kameraları, park halindeki donanımlı araçlarda toplam 4 aylık süreçteki her bir 5 hafta içi günü boyunca farklı OHTS koridor ve noktalarında 08:0018:00 saatleri arasında plaka okuma ve ortalama hiz tespiti yapmıştır.

\section{1. evre plaka okumaları}

1. Evre, 31.01.2013 - 29.03.2013 tarihleri arasında gerçekleșmiştir. Bu evrede, donanımlı araçlar hafta içi her gün saat 08:00-18:00 arasında OHTS koridorları 
giriş ve çıkış noktalarına konumlandırılmıştır. Kameralar vasıtasıyla araçların plakaları okunup, ortalama hız değerleri hesaplanmıştır. 1. Evre çalışması, elde edilen sonuçların etkinliğinin ölçülebilmesi açısından, uygulama süresi boyunca sürücülere duyurulmadan yürütülmüştür.

\section{Sistem duyurusu}

1. evrenin sonunda, İkinci Evre için sistemin hangi tarihlerde uygulanacağı ile ilgili üniversite personel ve öğrencilerine iki defa duyuru e-maili gönderilmiş, kampüs giriş kapılarına 3 adet yazılı ilan asılmış, ayrıca kampüs kapılarından giriş yapan araç sürücülerine el broşürleri dağıtılmıştır.

\section{2. evre plaka okumaları}

2. Evre, 09.04.2013 - 30.05.2013 tarihleri arasında gerçekleşmiştir. Bu evrede de birinci evrede olduğu gibi donanımlı araçlar hafta içi her gün saat 08:0018:00 civarında OHTS koridorlarında tespit edilmiş noktalara konumlandırılmıştır. Kameralar vasıtasıyla araçların plakaları okunup, ortalama hız değerleri hesaplanmıştır. Bu evrenin 1. evreden farkl; 1. evrede uygulamadan haberdar olmayan sürücülerin 2. Evrede haberdar edilmiș olmalarıdır. Böylece, aynı sürücülerin sistemin duyurulmasından önce ve sonraki ortalama hız farklılıkları kıyaslanabilecek, 1. Evredeki sürücülerin ortalama hız değerlerinin 2 . Evrede düşüş gösterip göstermediği de tespit edilecektir.

\subsection{Yöntem}

Excel formatında kaydedilen tüm veriler (ortalama hızı, tarih, saat bilgisi vs.) SAS (Statistical Analysis Software) programına yüklenmiş ve araştırma amaçları doğrultusunda çeşitli istatistiksel analizlere tabi tutulmuştur. "Hız toleransları dahilinde hız ihlali yapmayan sürücülerin", "hız ihlali yapan sürücülerin”, "așırı hız yapma davranıșı sergileyen sürücülerin" her bir güzergâh için ayrı ayrı 1. evre ve 2. evre ölçümleri arasındaki ortalama hız farklılıklarını bulmak için Independent Sample t test (Bağımsız iki grup arası farkların testi) kullanılmıştır. Çalışmada anlamlılık düzeyi 0.05 olarak belirlenmiştir. $\mathrm{Bu}$ üç türde hız davranışı sınırları belirlenirken ülkemizde uygulanan ceza oranları göz önüne alınmıştır. Ülkemizde OHTS ile denetlenen sürücülerin verilen hız limitlerini ne kadar geçerse cezası o oranda artmakta; sürücü hız limitini \%10-30 arası oranda aştığı zaman belirli bir miktarda para cezası kesilmekte, \%30'dan fazla geçerse bu sürücüler aşırı hız yapan sürücüler olarak tanımlanmakta ve en yüksek oranda para cezası kesilmektedir (IBB, 2013; Tedesceza, 2016).

\section{Araştırma Bulguları}

Bu kısımda 20, 30 ve $50 \mathrm{~km} / \mathrm{s}$ olmak üzere farklı hız limitlerine sahip güzergâhlarda duyuru sonrasında sistemin "hız limitlerine uyma", "hız yapma ve așırı hız yapma davranışlarını azaltma" hususlarında etkili olup olmadığı araștırılmıştır.

$20 \mathrm{~km} / \mathrm{s}$ hız limitine sahip güzergâhlarda (Tablo 2.) "20 km/s+ \%10" oranının altında hız davranışı gösteren (yani hız ihlali yapmayan) sürücülerin oranı 1. Evrede \% 2.08 iken, 2. Evrede \% 2.17 olarak artış göstermiştir. "20 km/s+ \%10" ile "20 km/s+ \%30" oranları arası hız davranışı göstererek hız ihlali yapan sürücülerin oranı 1. Evrede \% 1.13 iken, 2. Evrede \% 1.50 olarak artış göstermiştir. " $20 \mathrm{~km} / \mathrm{s}+\% 30$ ”' dan fazla hız yaparak "așırı hız yapma davranışı" sergileyen sürücülerin oranı 1. Evrede \% 45.67 iken, 2. Evrede \% 47.44 olarak artış göstermiştir.

Tablo 2. $20 \mathrm{~km} / \mathrm{s}$ hız limitli güzergâhlarda hız davranışına göre oranlar

\begin{tabular}{|c|c|c|c|c|c|}
\hline \multirow{2}{*}{$\begin{array}{l}\text { Hız Limiti } \\
(\mathrm{km} / \mathrm{s})\end{array}$} & \multirow[t]{2}{*}{ Hız davranışı } & \multicolumn{2}{|c|}{ 1. Evre } & \multicolumn{2}{|c|}{ 2. Evre } \\
\hline & & $\begin{array}{c}\text { Araç } \\
\text { sayısı }\end{array}$ & $\%$ & $\begin{array}{c}\text { Araç } \\
\text { sayısı }\end{array}$ & $\%$ \\
\hline 20 & “20 km/s+ \%10” altında & 46 & 2.08 & 48 & 2.17 \\
\hline 20 & $\begin{array}{l}\text { "20 km/s+ \%10" ile "20 } \\
\mathrm{km} / \mathrm{s}+\% 30 " \text { arası }\end{array}$ & 25 & 1.13 & 33 & 1.50 \\
\hline 20 & $\begin{array}{l}\text { "20 km/s+ \%30"dan } \\
\text { fazla }\end{array}$ & 1008 & 45.67 & 1047 & 47.44 \\
\hline
\end{tabular}

Tablo 3.'te $20 \mathrm{~km} / \mathrm{s}$ hız limitine sahip güzergâhlarda kurulan mobil OHTS'nin 1. ve 2. evre olmak üzere bu 3 kademedeki hız ölçümlerinin bulguları görülmektedir ve bu bulgular ışığında her bir kademe için, kurulan sistemin duyuru sonrasinda sürücülerin bu hız ortalamaları üzerinde etkisi olup olmadığını araştırmak amacıyla "Bağımsız iki grup arası farkların testi" (Independent Samples t test) yapılmıştır. 20 $\mathrm{km} / \mathrm{s}$ hız limitine sahip güzergâhlarda " $20 \mathrm{~km} / \mathrm{s}+$ \%10" oranının altında hız davranışı gösteren sürücülerin 1. Evredeki hız ortalaması $15.46 \mathrm{~km} / \mathrm{s}, 2$. Evredeki ortalama hız ortalaması ise $17,19 \mathrm{~km} / \mathrm{s}^{\prime}$ tir. Hız limitine uyan sürücülerin hız ortalamaları 2 . evrede 1. evreye göre yaklaşık $1.73 \mathrm{~km} / \mathrm{s}^{\prime}$ lik artış göstermektedir. Independent Samples $\mathrm{t}$ testi bu güzergâhlarda 2. Evredeki farkların anlamlı olduğunu göstermiştir. "20 km/s+ \%10" ile "20 km/s+ \%30" oranları arası hız davranışı göstererek hız ihlali yapan sürücülerin 1. Evredeki hız ortalaması $24.96 \mathrm{~km} / \mathrm{s}, 2$. Evredeki ortalama hız ortalaması ise $24.76 \mathrm{~km} / \mathrm{s}^{\prime}$ tir ve 2. evrede 1 . evreye göre yaklaşık $0.2 \mathrm{~km} / \mathrm{s}^{\prime} l i k$ bir azalma olmuştur. Independent Samples $t$ testi bu güzergâhlarda 2. Evredeki farkların anlamlı olmadığını göstermiştir. " $20 \mathrm{~km} / \mathrm{s}+\% 30$ "dan fazla hız yaparak "aşırı hız yapma davranışı" sergileyen sürücülerin 1. Evredeki hız ortalaması 49.86 km/s, 2. Evredeki ortalama hız ortalaması ise $47.62 \mathrm{~km} / \mathrm{s}^{\prime}$ tir ve 
2. evrede 1. evreye göre yaklaşık $2.24 \mathrm{~km} / \mathrm{s}^{\prime}$ lik bir azalma olmuştur. Independent Samples testi bu güzergâhlarda 2. Evredeki farkların anlamlı olduğunu göstermiştir. Yani aşırı hız yapan sürücülerin hız ortalamalarında 2. evrede anlamlı bir düşüş görülmektedir.

Tablo 3. Farklı hız davranışı gösterenlerin 1./2. evre ortalama hiz t testi

\begin{tabular}{|c|c|c|c|c|c|c|}
\hline Evre & $\begin{array}{l}\text { Hiz lim. } \\
(\mathrm{km} / \mathrm{s})\end{array}$ & Hız davranış & $\begin{array}{c}\text { Araç } \\
\text { sayısı }\end{array}$ & $\begin{array}{l}\text { Ort. hiz } \\
(\mathrm{km} / \mathrm{s})\end{array}$ & $\mathbf{t}$ & $\mathbf{p}$ \\
\hline $\begin{array}{l}\text { 1.Evre } \\
\text { 2.Evre }\end{array}$ & 20 & $\begin{array}{l}\text { "20 km/s+ \%10" } \\
\text { altında }\end{array}$ & $\begin{array}{l}46 \\
48\end{array}$ & $\begin{array}{l}15.46 \\
17.19 \\
\end{array}$ & -2.11 & 0.0380 \\
\hline $\begin{array}{l}\text { 1.Evre } \\
\text { 2.Evre }\end{array}$ & 20 & $\begin{array}{l}\text { "20 km/s+ \%10" } \\
\text { ile "20 km/s+ } \\
\% 30 " \text { arasl }\end{array}$ & $\begin{array}{l}25 \\
33\end{array}$ & $\begin{array}{l}24.96 \\
24.76\end{array}$ & 0.72 & 0.4789 \\
\hline $\begin{array}{l}\text { 1.Evre } \\
\text { 2.Evre }\end{array}$ & 20 & $\begin{array}{l}\text { " } 20 \mathrm{~km} / \mathrm{s}+\% 30 \text { " } \\
\text { dan fazla }\end{array}$ & $\begin{array}{l}1008 \\
1047\end{array}$ & $\begin{array}{l}49.86 \\
47.62\end{array}$ & 5.13 & $<.0001$ \\
\hline
\end{tabular}

*\% 5 anlamlılık düzeyi.

$30 \mathrm{~km} / \mathrm{s}$ hız limitine sahip güzergâhlarda (Tablo 4.) "30 km/s+ \%10" oranının altında hız davranışı gösteren (yani hız ihlali yapmayan) sürücülerin oranı 1. Evrede \% 21.65 iken, 2. Evrede \% 23.48 olarak artış göstermiştir. "30 km/s+ \%10" ile "30 km/s+ \%30" oranları arası hız davranışı göstererek hız ihlali yapan sürücülerin oranı 1. Evrede \% 13.49 iken, 2. Evrede \% 12.89 oranında düşüş göstermiştir. "30 km/s+ \%30"dan fazla hız yaparak "aşırı hız yapma davranışı" sergileyen sürücülerin oranı 1. Evrede \% 17.48 iken, 2. Evrede \% 11.01 olarak düşüş göstermiştir. Sistemin $30 \mathrm{~km} / \mathrm{s}$ hız limitli güzergâhlarda hem hız yapma hem de aşırı hız yapma davranışını azaltmak konusunda etkili olduğu gözlemlenmiştir.

Tablo 4. 30 km/s hız limitli güzergâhlarda hız davranışına göre oranlar

\begin{tabular}{|c|c|c|c|c|c|}
\hline \multirow{2}{*}{$\begin{array}{c}\text { Hiz Limit } \\
(\mathrm{km} / \mathrm{s})\end{array}$} & \multirow[t]{2}{*}{ Hız davranışı } & \multicolumn{2}{|c|}{ 1. Evre } & \multicolumn{2}{|c|}{ 2. Evre } \\
\hline & & $\begin{array}{c}\text { Araç } \\
\text { sayısı } \\
\end{array}$ & $\%$ & $\begin{array}{c}\text { Araç } \\
\text { sayısı }\end{array}$ & $\%$ \\
\hline 30 & $\begin{array}{l}\text { "30 km/s+ \%10" } \\
\text { altında }\end{array}$ & 6937 & 21.65 & 7525 & 23.48 \\
\hline 30 & $\begin{array}{l}\text { "300 km/s+\%10" ile } \\
\text { "30 km/s+ \%30" arası }\end{array}$ & 4323 & 13.49 & 4132 & 12.89 \\
\hline 30 & $\begin{array}{l}\text { “30 km/s+ \%30" dan } \\
\text { fazla }\end{array}$ & 5602 & 17.48 & 3529 & 11.01 \\
\hline
\end{tabular}

Tablo 5.'te $30 \mathrm{~km} / \mathrm{s}$ hız limitine sahip güzergâhlarda kurulan mobil OHTS'nin 1. ve 2. evre olmak üzere bu 3 kademedeki hız ölçümlerinin bulguları görülmektedir ve bu bulgular ışı̆̆ında her bir kademe için, kurulan sistemin duyuru sonrasında sürücülerin bu hız ortalamaları üzerinde etkisi olup olmadığını araştırmak amacıyla "Bağımsız iki grup arası farkların testi" (Independent Samples t test) yapılmıştır. 30 $\mathrm{km} / \mathrm{s}$ hız limitine sahip güzergâhlarda "30 km/s+ \%10" oranının altında hız davranışı gösteren sürücülerin 1. Evredeki hız ortalaması $26.73 \mathrm{~km} / \mathrm{s}, 2$. Evredeki ortalama hız ortalaması ise $29.97 \mathrm{~km} / \mathrm{s}$ 'tir ve ve 2. evrede 1. evreye göre yaklaşıl $3.24 \mathrm{~km} / \mathrm{s}^{\prime} l i k$ bir artış vardır. Bu sürücülerin duyuru yapılmadan önce ve sonraki hız ortalamaları karşılaștırılmıştır, Independent Samples $\mathrm{t}$ testi bu güzergâhlarda 2 . Evredeki farkların anlamlı olduğunu göstermiştir. "30 $\mathrm{km} / \mathrm{s}+\% 10$ " ile "30 km/s+ \%30" oranları arası hız davranışı göstererek hız ihlali yapan sürücülerin 1 . Evredeki hız ortalaması $36.48 \mathrm{~km} / \mathrm{s}, 2$. Evredeki ortalama hız ortalaması ise $36.35 \mathrm{~km} / \mathrm{s}$ 'tir ve 2 . evrede 1. evreye göre yaklaşık $0.13 \mathrm{~km} / \mathrm{s}^{\prime} l i k$ bir azalma olmuştur. Independent Samples $t$ testi bu güzergâhlarda 2. Evredeki farkların anlamlı olduğunu göstermiştir. Yani bu güzergâhlardaki hız düşüşü miktarı sayısal olarak $0.13 \mathrm{~km} / \mathrm{s}^{\prime}$ lik düşük bir miktar olarak görülse de, istatistiksel anlamda önemli bir fark olduğu görülmektedir. "30 km/s+ \%30"dan fazla hız yaparak "aşırı hız yapma davranışı" sergileyen sürücülerin 1. Evredeki hız ortalaması $45.51 \mathrm{~km} / \mathrm{s}, 2$. Evredeki ortalama hız ortalaması ise $44.80 \mathrm{~km} / \mathrm{s}^{\prime}$ tir ve ve 2. evrede 1. evreye göre yaklaşık $0.71 \mathrm{~km} / \mathrm{s}^{\prime} l i k$ bir azalma olmuştur. . Independent Samples t testi bu güzergâhlarda 2. Evredeki farkların anlamlı olduğunu göstermiştir. Yani bu güzergâhlardaki hız düşüşü miktarı sayısal olarak $0.71 \mathrm{~km} / \mathrm{s}^{\prime} l i k$ düşük bir miktar olarak görülse de, așırı hız yapan sürücülerin hız ortalamalarında 2. Evrede istatistiksel olarak anlamlı bir düşüş görülmektedir.

Tablo 5. Farklı hız davranışı gösterenlerin 1./2. evre ortalama hiz t testi

\begin{tabular}{|c|c|c|c|c|c|c|}
\hline Evre & $\begin{array}{l}\text { Hiz lim. } \\
(\mathrm{km} / \mathrm{s})\end{array}$ & Hiz davranış & $\begin{array}{c}\text { Araç } \\
\text { sayısı }\end{array}$ & $\begin{array}{l}\text { Ort. hiz } \\
(\mathrm{km} / \mathrm{s})\end{array}$ & $\mathbf{t}$ & $\mathbf{p}$ \\
\hline $\begin{array}{l}\text { 1.Evre } \\
\text { 2.Evre }\end{array}$ & 30 & $\begin{array}{l}\text { "30 km/s+ \%10" } \\
\text { altında }\end{array}$ & $\begin{array}{l}6937 \\
7525\end{array}$ & $\begin{array}{l}26.73 \\
29.97\end{array}$ & -2.54 & 0.0112 \\
\hline $\begin{array}{l}\text { 1.Evre } \\
\text { 1.Evre }\end{array}$ & 30 & $\begin{array}{l}\text { "30 km/s+\%10" ile "30 } \\
\mathrm{km} / \mathrm{s}+\% 30 " \text { arası }\end{array}$ & $\begin{array}{l}4323 \\
4323\end{array}$ & $\begin{array}{l}36.48 \\
36.35 \\
\end{array}$ & 3.40 & 0.0007 \\
\hline $\begin{array}{l}\text { 1.Evre } \\
\text { 2.Evre }\end{array}$ & 30 & $\begin{array}{l}\text { “30 km/s+ \%30" dan } \\
\text { fazla }\end{array}$ & $\begin{array}{l}5602 \\
3529\end{array}$ & $\begin{array}{l}45.51 \\
44.80\end{array}$ & 7.04 & $<.0001$ \\
\hline
\end{tabular}

$50 \mathrm{~km} / \mathrm{s}$ hız limitine sahip güzergâhlarda (Tablo 6.) “50 km/s+ \%10" oranının altında hız davranışı gösteren (yani hız ihlali yapmayan) sürücülerin oranı 1. Evrede \% 23.69 iken, 2. Evrede \% 38.58 olarak artış göstermiştir. "50 km/s+ \%10" ile " $50 \mathrm{~km} / \mathrm{s}+\% 30$ " oranları arası hız davranışı göstererek hız ihlali yapan sürücülerin oranı 1. Evrede \% 16.72 iken, 2. Evrede \% 12.58 olarak düşüş göstermiştir. " $50 \mathrm{~km} / \mathrm{s}+\% 30$ "dan fazla hız yaparak "aşırı hız yapma davranışı" sergileyen sürücülerin oranı 1. Evrede \% 4.36 iken, 2. Evrede \% 4.06 olarak düşüş göstermiştir. Sistemin 50 $\mathrm{km} / \mathrm{s}$ hız limitli güzergâhlarda hem hız yapma hem de aşırı hız yapma davranışını azaltmak konusunda etkili olduğu gözlemlenmiştir.

Tablo 6. 50 km/s hız limitli güzergâhlarda hız davranışına göre oranlar

\begin{tabular}{c}
$\begin{array}{c}\text { Hız limiti } \\
(\mathrm{km} / \mathrm{s})\end{array}$ \\
\hline
\end{tabular}




\begin{tabular}{clcccc}
\hline & Sayı & \% & Sayı & \% \\
\hline 50 & $\begin{array}{l}\text { “50 km/s+\%10" } \\
\text { altında }\end{array}$ & 2708 & 23.69 & 4411 & 38.58 \\
\hline 50 & $\begin{array}{l}\text { “50 km/s+ \%10" ile } \\
\text { “50 km/s+\%30" arası }\end{array}$ & 1912 & 16.72 & 1438 & 12.58 \\
\hline $50 \quad \begin{array}{l}\text { “50 km/s+\%30" dan } \\
\text { fazla }\end{array}$ & 499 & 4.36 & 464 & 4.06
\end{tabular}

Tablo 7.'de $50 \mathrm{~km} / \mathrm{s}$ hız limitine sahip güzergâhlarda kurulan mobil OHTS'nin 1. ve 2. evre olmak üzere bu 3 kademedeki hız ölçümlerinin bulguları görülmektedir ve bu bulgular ışığında her bir kademe için, kurulan sistemin duyuru sonrasında sürücülerin bu hız ortalamaları üzerinde etkisi olup olmadığını araștırmak amacıyla "Bağımsız iki grup arası farkların testi" (Independent Samples t test) yapılmıştır. 50 $\mathrm{km} / \mathrm{s}$ hız limitine sahip güzergâhlarda " $50 \mathrm{~km} / \mathrm{s}+$ $\% 10$ " oranının altında hız davranışı gösteren sürücülerin 1. Evredeki hız ortalaması $46.77 \mathrm{~km} / \mathrm{s}, 2$. Evredeki ortalama hız ortalaması ise $44.94 \mathrm{~km} / \mathrm{s}^{\prime}$ tir ve 2. evrede 1. evreye göre yaklaşık $1.83 \mathrm{~km} / \mathrm{s}^{\prime} l i k$ bir düşüş vardır. Bu sürücülerin duyuru yapılmadan önce ve sonraki hız ortalamaları karșılaștırılmıștır. Independent Samples $\mathrm{t}$ testi bu güzergâhlarda 2 . Evredeki farkların anlamlı olduğunu göstermiştir. " 50 $\mathrm{km} / \mathrm{s}+\% 10$ " ile "50 km/s+ \%30" oranları arası hız davranışı göstererek hız ihlali yapan sürücülerin 1 . Evredeki hız ortalaması 59.78, 2. Evredeki ortalama hız ortalaması ise $59.69 \mathrm{~km} / \mathrm{s}^{\prime} \mathrm{d} ı \mathrm{r}$ ve 2 . evrede 1 . evreye göre yaklaşık $0.09 \mathrm{~km} / \mathrm{s}^{\prime}$ lik bir azalma olmuștur. Independent Samples $\mathrm{t}$ testi bu güzergâhlarda 2. Evredeki farkların anlamlı olmadığını göstermiştir. $50 \mathrm{~km} / \mathrm{s}$ hız limitine sahip güzergâhlarda " $50 \mathrm{~km} / \mathrm{s}+\% 30$ "' dan fazla hız yaparak "aşırı hız yapma davranışı" sergileyen sürücülerin 1 . Evredeki hız ortalaması $71.77 \mathrm{~km} / \mathrm{s}, 2$. Evredeki ortalama hız ortalaması ise $71.97 \mathrm{~km} / \mathrm{s}$ 'tir ve 2 . evrede 1. evreye göre yaklaşık $0.2 \mathrm{~km} / \mathrm{s}^{\prime}$ lik bir artış olmuştur. Independent Samples $t$ testi bu güzergâhlarda 2 . Evredeki farkların anlamlı olmadığını göstermiştir. Yani bu güzergâhlarda görünüște "hız artışı" olsa dahi, istatistiksel anlamda fark olmadığı için, bu güzergâhlarda "aşırı hız yapma davranışında" artış olmamıştır denilebilir.

Tablo 7. Farklı hız davranışı gösterenlerin 1./2. evre ortalama hiz t testi

\begin{tabular}{|c|c|c|c|c|c|c|}
\hline Evre & $\begin{array}{l}\text { Hoz limit } \\
(\mathrm{km} / \mathrm{s})\end{array}$ & Hız davranış & $\begin{array}{l}\text { Araç } \\
\text { sayısı }\end{array}$ & $\begin{array}{l}\text { Ort. hiz } \\
(\mathrm{km} / \mathrm{s})\end{array}$ & $\mathbf{t}$ & $\mathbf{p}$ \\
\hline $\begin{array}{l}\text { 1.Evre } \\
\text { 2.Evre }\end{array}$ & 50 & $\begin{array}{l}\text { "50 km/s+ \%10" } \\
\text { altında }\end{array}$ & $\begin{array}{l}2708 \\
4411\end{array}$ & $\begin{array}{l}46.77 \\
44.94\end{array}$ & 9.95 & $<.0001$ \\
\hline $\begin{array}{l}\text { 1.Evre } \\
\text { 2.Evre }\end{array}$ & 50 & $\begin{array}{l}\text { "50 km/s+\%10" ile "50 } \\
\mathrm{km} / \mathrm{s}+\% 30 " \text { arası }\end{array}$ & $\begin{array}{l}1912 \\
1438\end{array}$ & $\begin{array}{l}59.78 \\
59.69 \\
\end{array}$ & 0.91 & 0.3634 \\
\hline $\begin{array}{l}\text { 1.Evre } \\
\text { 2.Evre }\end{array}$ & 50 & $\begin{array}{l}\text { “50 km/s+ \%30”' dan } \\
\text { fazla }\end{array}$ & $\begin{array}{l}499 \\
464\end{array}$ & $\begin{array}{l}71.77 \\
71.97\end{array}$ & -0.59 & 0.5559 \\
\hline
\end{tabular}

*\% 5 anlamlılık düzeyi.

\section{Sonuç ve Tartışma}

$20 \mathrm{~km} / \mathrm{s}$ hız limitine sahip güzergâhlarda duyuru sonrasında, hız limitine uyan sürücülerin oranı $\% 0.09$ olarak artış, hız ortalamaları ise $1.73 \mathrm{~km} / \mathrm{s}^{\prime}$ lik anlamlı bir artış göstermektedir. Aşırı olmayan hız ihlali yapan sürücülerin oranı 2. Evrede \% 1.50 olarak artış; hız ortalamalarında 2 . evrede $0.2 \mathrm{~km} / \mathrm{s}^{\prime}$ lik anlaml olmayan bir azalma olmuştur. Aşırı hız yapma davranışı sergileyen sürücülerin oranı 2. Evrede \% 1.77 oranında artış göstermiş, fakat hız ortalamalarında 2. evrede 1. evreye göre yaklaşık 2.24 $\mathrm{km} / \mathrm{s}$ 'lik anlamlı bir düşüş olmuştur. Kurulan sistemin $20 \mathrm{~km} / \mathrm{s} \mathrm{hız} \mathrm{limitine} \mathrm{sahip} \mathrm{güzergâhlarda} \mathrm{hız} \mathrm{limitine}$ uyumu artırdı̆̆ı, aşırı hız yapma eğilimini azalttığı görülmektedir. Bu güzergâhlar; aliyman geometrik özelliğine sahip oldukları, kavşak ve kasis bulundurmadıkları için dönüş yapan ve yandan katılan taşıtların sebep olduğu veya denetimden kaynaklanan bir hız sınırlaması söz konusu değildir, bu sebepten ötürü hız sınırlarına her iki evrede de hız sınırına sağlanan uyum düşük seviyededir. $\mathrm{Bu}$ güzergahlarda hız sınırlarının, sürücülerin bakış açısından makul olarak görülmediği ve optimal bir hız sinırı düzenlemesi yapılması gerektiği düşünülmektedir.

$30 \mathrm{~km} / \mathrm{s}$ hız limitine sahip güzergâhlarda hız ihlali yapmayan sürücülerin oranı 2 . Evrede $\% 1.83$ oranında artış göstermiş, ortalama hız ortalamasında ise 2 . evrede 1 . evreye göre yaklaşı $3.24 \mathrm{~km} / \mathrm{s}^{\prime}$ lik anlamlı bir artış vardır. Aşırı olmayan hız ihlali yapan sürücülerin oranı \% 0.6 oranında düşüş göstermiş, ortalama hiz ortalamasında 2. evrede 1 . evreye göre yaklaşık $0.13 \mathrm{~km} / \mathrm{s}^{\prime}$ lik anlamlı bir azalma olmuştur. Aşırı hız yapma davranışı sergileyen sürücülerin oranı 2. Evrede \% 6.47 oranında düşüş göstermiștir, hız ortalaması ise 2. evrede 1 . evreye göre yaklaşık 0.71 $\mathrm{km} / \mathrm{s}^{\prime} l i k$ anlamlı bir düşüş olmuştur. Sistemin $30 \mathrm{~km} / \mathrm{s}$ hız limitli güzergâhlarda hem hız limitlerine uyumu artırma, hem hız yapma hem de aşırı hız yapma davranışını azaltmak konusunda etkili olduğu gözlemlenmiştir. Her iki dönemde de bu güzergâhların fiziki durumuna göre araç sürücüsünde oluşturduğu hız limiti hissinin etkili olduğu, bu yüzden hız limitlerine uyumun düşük olduğu düşünülmektedir.

$50 \mathrm{~km} / \mathrm{s}$ hız limitine sahip güzergâhlarda hız ihlali yapmayan sürücülerin oranı 2 . Evrede $\% 14.89$ oranında artış, ortalama hız ortalamasında ise 2. evrede 1. evreye göre yaklaşık $1.83 \mathrm{~km} / \mathrm{s}^{\prime}$ lik anlamlı bir düşüş vardır. Așırı olmayan hız ihlali yapan sürücülerin oranı 2 . Evrede $\% 4.14$ oranında düşüş, ortalama hiz ortalamasında ise 2 . evrede 1 . evreye göre yaklaşı $0.09 \mathrm{~km} / \mathrm{s}^{\prime}$ lik anlamlı olmayan bir azalma olmuştur. Aşırı hız yapma davranıșı sergileyen sürücülerin oranı 2. Evrede $\% 0.30$ oranında düşüş göstermiş, ortalama hız ortalamasında 2 . evrede 1 . evreye göre yaklaşı $0.2 \mathrm{~km} / \mathrm{s}^{\prime}$ lik anlamlı olmayan bir artış olmuștur. Yani bu güzergâhlarda görünüște "hız artışı" olsa dahi, istatistiksel anlamda fark olmadığı için, bu güzergâhlarda "aşırı hız yapma davranışında" 
artış olmamıștır denilebilir. Sistemin $50 \mathrm{~km} / \mathrm{s} \mathrm{hız}$ limitli güzergâhlarda hız limitine uyum artışının yüksek oranda olmasının yanı sıra, hem aşırı olmayan hız yapma hem de aşırı hız yapma davranışını azaltmak konusunda düşük oranlarda da olsa etkili olduğu gözlemlenmiştir.

Tüm güzergâhlarda her ne kadar ortalama hızlar 2 . Evrede düşse de, her 2 evrede de özellikle $20 \mathrm{~km} / \mathrm{s}$ hız limitli güzergâhlarda hız sınırına sağlanan uyum düşük seviyededir. Bu güzergâhlarda uygulanan hız sınırlarının, sürücülerin bakış açısından makul olarak görülmediği, yolun fiziki durumuna göre araç sürücüsünde oluşturduğu hız limiti hissinin 2 evrede de etkili olmaya devam ettiği düşünülmektedir. Bu güzergâhlarda optimal bir hız sınırı düzenlemesi yapılması gerektiği düşünülmektedir. Sonuçlar olumlu görülse de hız sınırlarına daha yüksek bir uyum, ihlallerin takibinde bir ceza uygulama yaptırımı ile sağlanabilir.

\section{Teşekkür}

Bu çalışmayı 2011010102007 Numaralı Proje ile maddi olarak destekleyen Akdeniz Üniversitesi Bilimsel Araştırma Projeleri Koordinasyon Birimine teşekkür ederiz.

\section{Kaynaklar}

Australian Transport Council, 2011. National Road Safety Strategy 2011-2020. Australian Transport Council, Canberra, ACT: ATC.

Automatic Number Plate Recognition (ANPR) Systems - Code of Practice, 2014. Erișim Tarihi: 01.01.2015.https://www.cornwall.gov.uk/m edia/3118236/anpr-cop-5th-release-june2015.pdf

Cameron M., Delaney A., Diamantopoulou K, 2003. Scientific Basis for the Strategic Directions of the Safety Camera Program in Victoria. Melbourne: Monash University Accident Research Centre Reports, 202, 78.

Cameron, M., 2008. Development of Strategies for Best Practice in Speed Enforcement in Western Australia, Supplementary Report, Monash University Accident Research Centre, Melbourne.

Cascetta, E., Punzo, V., Montanino, M., 2011. Empirical Evidence of Speed Management Effects on Traffic Flow at Freeway Bottleneck, In TRB 2011 Annual Meeting.

Collins, G., 2007. Traffic Flow İmprovements with Average Speed Enforcement, In International
Conference on Intelligent Transport Systems, Birmingham, United Kingdom.

De Pauw, E., Daniels, S., Brijs, T, Hermans, E., Wets, G. 2014. Automated Section Speed Control on Motorways: An Evaluation of the Effect on Driving Speed, Accident Analysis \& Prevention, 73, 313-322.

Fleiter, J., Lewis, I.M., Watson, B.C., 2013. Promoting a More Positive Traffic Safety Culture in Australia : Lessons Learnt and Future Directions. Journal of the Australasian College of Road Safety Conference, 6-8 Kasım 2013, South Australia, 25(1), 27.

Gains, A., Nordstrom, M., Heydecker, B., Shrewsbury, J., Mountain, L., Maher, M., 2005. The National Safety Camera Programme: Four-Year Evaluation Report. PA Consulting Group, London.

Gil, MJM., Malenstein, UPMJ, 2007. Innovative Technology for Monitoring Traffic,Vehicles and Drivers, Police Enforcement Policy and Programmes on European Roads.

Grunnan, T., Vaa, T., Ulleberg, P., Malenstein, J., Zaidel, D., Kauvo, K., 2008. Implications of Innovative Technology for the Key Areas in Traffic Safety: Speed, Drink Driving and Restraint Systems, Police Enforcement Policy and Programmes on European Roads, Europe.

IBB, 2013. E-5 'e akıllı trafik yönetim sistemi. Erişim Tarihi: 03.01.2013.http://www.ibb.gov.tr/trTR/Pages/Haber.aspx?NewsID=20875\#.WJD 2fFWLSpo.

Kallberg, V. P., Zaidel, D., Vaa, T., Malenstein, J., Siren, A., Gaitanidou, E., 2008. Police Enforcement Policy and Programmes on European Roads, Final Report.

Kloeden, C.N., McLean, A.J., Glonek, G., 2002. Reanalysis of Travelling Speed and the Risk of Crash Involvement in Adelaide South Australia. Department of Transport and Regional Services, Australian Transport Safety Bureau, Canberra.

Korthof, E.W., 2014. Effects of Section Control on Traffic Safety at Dutch Motorways. Delft University of Technology, Master Thesis, 202, Delft.

Koy, T., Benz, S., 2009. Automatic Time-Over-Distance Speed Checks İmpacts on Driving Behaviour and Traffic Safety. In the 6th ITS World 
Congress and Exhibition on Intelligent Transport Systems and Services, Stockholm.

KTK, 2013. Karayolları Trafik Kanunu'nun 2918 Sayılı Kanun EK 16 Maddesi Kapsamında Trafik Hizmetlerinde Kullanılacak Teknik Teçhizatlar İçin Genel Yeterlilik Esasları. Erişim Tarihi: 01.02.2016. https://www.trafik.gov.tr/SiteAssets/Trafik \%20Kitapl\%C4\%B1k/Mevzuat/KTK_Ek16_U sulEsaslar.pdf

Lynch, M., 2010. Forward Design Study: Introduction of Point to Point Speed Cameras in the ACT. AECOM Australia, Canberra.

Malenstein, J., 1997. Automated Video Speed Enforcement and Trajectory Control Combined With Fully Automated Processing. Dutch National Police Agency, Traffic and Transport Division, Driebergen, Netherlands.

Montella, A., Imbriani, L., Marzano, V., Mauriello, 2014. Effects on Speed and Safety of Point-ToPoint Speed Enforcement Systems: Evaluation on the Urban Motorway A56 Tangenziale di Napoli. Accident Analysis \& Prevention, 75, 164-178.

Montella, A., Punzo, V., Chiaradonna, S., Mauriello, F., Montanino, M., 2015. Point-to-Point Speed Enforcement System: Speed Limits Design Criteria and Analysis of Drivers' Compliance. Transport. Res. Part C 53, 1-18.

Nilsson, G., 2004. Traffic Safety Dimensions and the Power Model to Describe the Effect of Speed on Safety. Bulletin 221. Lund Institute of Technology, Lund.

Organisation for Economic Co-Operation and Development, 2006. Speed Management. Erişim Tarihi: 01.02.2013. http://www.itfoecd.org/sites/default/files/docs/06speed.p df

Orozova-Bekkevold, I., Martinez, M., Akkermans, L., 2007. Needs and Objectives of the EC Regarding TLE Data in the Light of Data Availability and the Technical Aspects of Data Collection and Exchange. Erişim Tarihi: 01.02.2013.http://www.vtt.fi/files/sites/pep per/pepper_w12_wp2.pdf

Ornek, M.N., Lorasokkay, M.A., Çevik, İ., Özek, T., 2013. Trafikte Kullanılan Bazı Elektronik Denetleme Sistemleri ve Koridor Hiz Tespit Sistemi Uygulamasında (TEDES) Konya Örneği. 4. Karayolu Trafik Güvenliği Sempozyumu ve Sergisi, Ankara.
Parliamentary Travelsafe Committee, 2008. Report on the Inquiry into Automatic Number Plate Recognition Technology. Report No. 51. Brisbane: Parliamentary Travelsafe Committee.

Schwab, N., 2006. For a Better Safety and Traffic Flow Optimisation During Peak Periods: Speed Control Experimentation on the A7 Motorway. In 12th World Congress on Intelligent Transport Systems, 06-10 November, France.

Soole, D., Fleiter, J., Watson, B., 2012. Point-to-Point Speed Enforcement. Report No: AP-R415-12. $165 p$.

Speed Check Services, 2009. SPECS Safety CamerasM4 10-12 Technology Upgrade. Erișim Tarihi: 01.02.2013.http://www.speedcheck.co.uk/i mages/M4_Case_Study.pdf

Stefan, C., 2005. Automatic Speed Enforcement on the A13 Motorway (NL): Rosebud WP4 - Case B Report. Austrian Road Safety Board (KfV), Austria.

Tedesceza, 2016. 2016 Tedes Cezası Ne Kadar? http://tedesceza.com/tedes-cezasi/

Townsend, E., 2006. Enforcement Monitor (No. 6). Brussels, Belguim: ETSC.

Young, K.L., Regan, M. A., 2007. Intelligent Transport Systems to Support Police Enforcement of Road Safety Laws. ATSB Research and Analysis Report No: 2007-02, 62p. 